\title{
SISTEM INFORMASI INVENTORY CONTROL LOGISTIK BERBASIS CLIENT SERVER PT. KEONG NUSANTARA ABADI
}

\author{
Ferly Ardhy \\ Dosen Sistem Informasi, STMIK Dian Cipta Cendikia Kotabumi \\ E-Mail : Ferly@dcc.ac.id
}

\begin{abstract}
ABSTRAK
PT. Keong Nusantara Abadi merupakan salah satu perusahaan yang berperan aktif dalam bidang produksi makanan dan minuman olahan. PT. Keong Nusantara Abadi berlokasi di Bumisari Natar Lampung Selatan. Sebagai perusahaan yang sudah lama muncul pada tahun 1984, PT. Keong Nusantara Abadi sudah sangat mampu bersaing dengan perusahaan lain yang bergerak dalam bidang yang sama.

Tujuan dari penulisan ini adalah untuk menghasilkan Sistem Informasi Inventory Control Logistik Berbasis Client Server pada PT. Keong Nusantara Abadi. Metode pengumpulan data yang dilakukan dalam pengumpulan data perusahaan dengan melakukan wawancara, pengamatan, tinjauan pustaka dan dokumentasi. Metode penelitian pengembangan sistem, yaitu System Development Life Cyce (SDLC) model waterfall, dimana bila tahap pertama belum selesai maka tidak dapat melanjutkan ketahap yang berikutnya.

Berdasarkan Sistem Informasi Inventory Control Logistik yang telah diuraikan pada pembahasan maka sistem ini dikembangkan dengan menggunakan bahasa pemrograman visual basic 6.0, yang dapat membantu proses pengolahan data barang, barang masuk, barang keluar, purchase order dan pencarian data serta dalam pembuatan laporan sistem informasi ini lebih cepat dari pada sistem sebelum nya.
\end{abstract}

Kata kunci : Sistem Informasi Inventory Control, Client Server, visual basic 6.0

ABSTRACT
PT. Keong Nusantara Abadi is one of the companies that play an active role in the field of production of processed foods and beverages. PT. Keong Nusantara Abadi is located in Bumisari Natar Lampung Selatan. As a long-standing company in 1984, PT. Keong Nusantara Abadi has been very able to compete with other companies engaged in the same field.

The purpose of this paper is to produce Inventory Control Information System Based Client Server Logistics at PT. Keong Nusantara Abadi. Data collection methods are conducted in the collection of company data by conducting interviews, observations, literature review and documentation. System development research method, namely System Development Life Cyce $(S D L C)$ waterfall model, where if the first stage is not completed then can not continue the next stage.

Based on Logistic Inventory Control Information System that has been described in the discussion then the system is developed by using visual basic programming language 6.0, which can help the process of data processing goods, goods entry, goods out, purchase orders and search data and in making this information system report more faster than on the system before it.

Keywords: Inventory Control Information System, Client Server, visual basic 6.0 


\section{PENDAhuluan}

Di era globalisasi seperti saat ini setiap perusahaan tidak dapat menghindari persaingan, dengan persaingan - persaingan tersebut sebuah perusahaan akan berkembang menjadi besar dan maju jika didukung oleh manajemen yang baik serta sumber daya yang handal. Informasi sudah menjadi sebuah kebutuhan mutlak bagi manusia karena tuntutan itulah, dalam penyajian informasi pun harus cepat, tepat, dan efesien. Komputer memiliki peran penting dalam penyajian informasi, terutama pada perusahaan - perusahaan yang memanfaatkan komputer sebagai alat pengolahan data. Oleh karena itu dibutuhkan sumber daya manusia yang handal dan mampu mengoprasikan komputer dengan baik untuk mengaplikasikan masalah yang dihadapi dengan kecanggihan teknologi yang ada.

PT. Keong Nusantara Abadi merupakan salah satu perusahaan yang berperan aktif dalam bidang produksi makanan dan minuman olahan. PT. Keong Nusantara Abadi berlokasi di Bumisari Natar Lampung Selatan. Sebagai perusahaan yang sudah lama muncul pada tahun 1984, PT. Keong Nusantara Abadi sudah sangat mampu bersaing dengan perusahaan lain yang bergerak dalam bidang yang sama. Namun sistem yang ada pada perusahaan ini masih manual dimana ketika barang masuk dan keluar dari gudang logistik, karyawan hanya mencatat pada form buku barang yang telah tersedia. Sering terdapat kesalahan pencatatan dari tercampurnya data barang satu dengan yang lain, mines stok barang, ketidaksesuaian data barang dan kesalahan - kesalahan lain yang tidak diinginkan.

Pencatatan pembukuan barang sering kali pada saat pengecekan barang terlalu banyak membuang waktu dan laporan laporan yang diberikan kepada pimpinan sering kali mengalami keterlambataan dan ketidaksesuaian pada jumlah barang dan data yang diberikan. Terlebih lagi saat bagian produksi ingin memesan bahan baku untuk keperluan produksi, dimana bagian tersebut kesulitan untuk mengetahui stok barang yang ada karena stok barang masih dicatat dalam satu buku dan buku tersebut berada pada bagian logistik. Oleh sebab itu, pemanfaatan dan kecanggihan teknologi yang ada dapat dimanfaatkan sebagai alat penunjang melakukan kegitan tersebut yaitu dengan mengaplikasikan proses penolahan pengendalian barang logistik yang bisa dibuat secara terkomputerisasi dengan memanfaatkan program aplikasi berbasis client server, sehingga akan sangat memudahkan para pekerja dalam proses pengolahan pengendalian barang logistik pada perusahaan PT. Keong Nusantara Abadi.

\section{METODE PENELITIAN}

Dalam penelitian ini dilakukan rekayasa perangkat lunak dimana prosesnya dibuat dengan rekayasa sistem Alan Dennis dan Barbara $\mathrm{H}$ Wixom menyampaikan beberapa tahap untuk menggunakan salah satu metode penelitian pengembangan sistem, yaitu System Development Life Cyce (SDLC) model waterfall, dimana bila tahap pertama belum selesai maka tidak dapat melanjutkan ketahap yang berikutnya.

\section{Tahapan Metode Waterfall}

1. Planning (Perencanaan)

Langkah pertama dari proses ini adalah dengan mengidentifikasi permasalahan yang ada pada gudang logistik, sehingga dapat tercapai suatu penyelesaian yang maksimal.

2. Analysis (Analisis)

Pada tahap ini pembuat sistem akan melakukan observasi dan pengamatan pada sistem lama, kemudian memanfaatkan dan mengembangkan peluang serta membangun konsep untuk semua sistem baru.

3. Design (Perancangan)

Tahap perancancangan dilakukan untuk menetapkan bagaimana sistem akan dioperasikan. Hal ini berkaitan dengan menentukan perangkat keras, perangkat lunak, tampilan program, form dan laporan yang akan dipakai. Selain itu juga perlu menspesifikasi program, database dan file yang yang akan dibutuhkan di gudang logistik. 
4. Implementation (Implementasi)

Merupakan tahap berikutnya untuk menterjemahkan data atau pemecah yang telah dirancang kedalam bahasa pemograman komputer yang telah ditentukan. Semua tahap ini didesain perangkat lunak sebagai sebuah program lengkap atau unit program.

5. Maintenance (Perawatan)

Sistem telah dipasang dan digunakan, termasuk didalamnya proses pemeliharaan dan perbaikan kesalahan. Perangkat lunak yang telah selesai dibuat dapat mengalami perubahanperubahan atau penambahan sesuai dengan permintaan user atau perubahan sistem.

\subsection{Landasan Teori}

\subsubsection{Sistem}

Sistem adalah kumpulan dari beberapa elemen yang saling berintegrasi untuk mencapai tujuan tertentu. Elemenelemen yang mewakili suatu sistem secara umum adalah masukan (input), pengolahan (processing) dan keluaran (output).

\subsubsection{Informasi}

Informasi adalah data yang diolah menjadi bentuk yang berguna dan menjadi berarti bagi penerimanya. Kegunaan informasi adalah untuk mengurangi ketidakpastian di dalam proses pengambilan keputusan tentang suatu keadaan. Suatu informasi dikatakan bernilai bila manfaatnya lebih efektif dibandingkan dengan biaya untuk mendapatkan informasi tersebut. Kualitas informasi sangat dipengaruhi atau ditentukan oleh beberapa hal yaitu :
a. Relevan (Relevancy)
b. Akurat (Accurancy)
c. Tepat waktu (Time liness)
d. Ekonomis (Economy)
e. Efisien (Efficiency)
f. Ketersediaan (Availability)
g. Dapat dipercaya (Reliability)
h. Konsisten

\subsubsection{Sistem Informasi Berbasis Komputer}

Computer Based Information System (CBIS) atau yang dalam Bahasa Indonesia disebut juga Sistem Informasi Berbasis Komputer merupakan sistem pengolah data menjadi sebuah informasi yang berkualitas dan dipergunakan untuk suatu alat bantu pengambilan keputusan. Sistem Informasi yang akurat dan efektif, dalam kenyataannya selalu berhubungan dengan istilah "computer-based" atau pengolahan informasi yang berbasis pada komputer. Sistem Informasi "berbasis komputer" mengandung arti bahwa komputer memainkan peranan penting dalam sebuah sistem informasi. Secara teori, penerapan sebuah Sistem Informasi memang tidak harus menggunakan komputer dalam kegiatannya. Tetapi pada prakteknya tidak mungkin sistem informasi yang sangat kompleks itu dapat berjalan dengan baik jika tanpa adanya komputer. Sistem Informasi merupakan sistem pembangkit informasi. Dengan integrasi yang dimiliki antar subsistemnya, sistem informasi akan mampu menyediakan informasi yang berkualitas, tepat, cepat dan akurat sesuai dengan manajemen yang membutuhkannya.

\subsubsection{Inventory Control (Persediaan Pengendalian}

Menurut Rangkuti (2004:2) Persediaan adalah "Persediaan merupakan bahanbahan,bagian yang disediakan dan bahanbahan dalam proses yang terdapat dalam perusahaan untuk proses produksi,serta barang-barang jadi atau produk yang disediakan untuk memenuhi permintaan dari konsumen atau pelanggan setian waktu."

\section{HASIL DAN PEMBAHASAN}

HASIL

a. Form Login

Form login ini terdiri dari 2 textfield dan 2 button 


\begin{tabular}{|l|l|l|}
\hline 1 & Txt_user & Digunakan untuk memasukan username \\
\hline 2 & Txt_pass & Digunakan untuk memasukan password \\
\hline 3 & Btn_masuk & Digunakan untuk memanggil fungsi validasi login \\
\hline 4 & Btn_keluar & Digunakan untuk keluar dari aplikasi \\
\hline
\end{tabular}

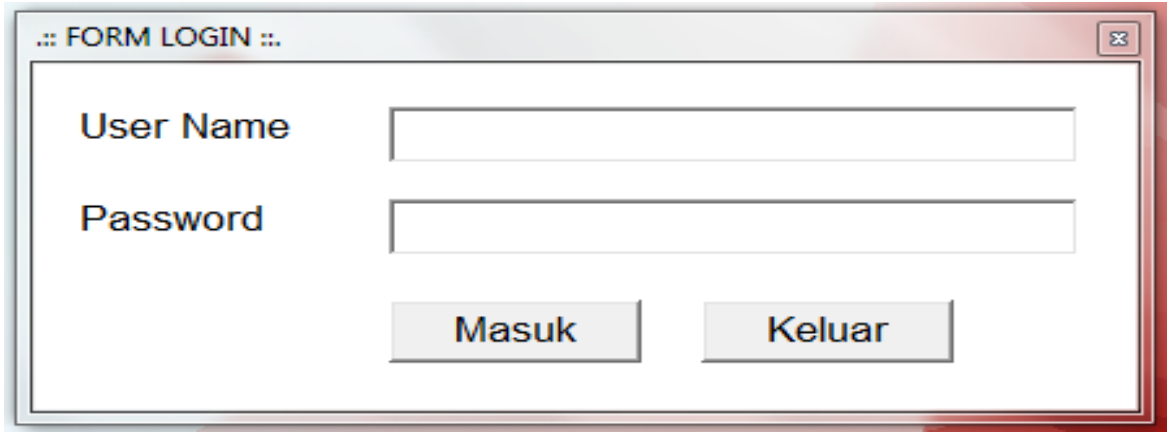

Gambar 1 Tampilan Form Login

\section{b. Form Menu Utama}

Form utama ini memiliki beberapa Menu pilihan yaitu :

\begin{tabular}{|l|l|ll|}
\hline 1 & Menu Master & 1. & Barang \\
2. & User \\
\hline 2 & Menu & 1. & Barang \\
& Transfer & Masuk \\
& & 2. & $\begin{array}{l}\text { Barang } \\
\text { Keluar } \\
\end{array}$ \\
& & 3. & $\begin{array}{l}\text { Purchase } \\
\text { Order }\end{array}$ \\
\hline 3 & Menu & 1. & Barang \\
\hline
\end{tabular}

\begin{tabular}{|l|l|rl|}
\hline Laporan & 2. & Masuk \\
& & Barang \\
& & Keluar \\
& & 3. & Purchase \\
& & Order \\
& & 4. & Rekap Barang \\
& & Masuk \\
& 5. & Rekap Barang \\
& & Keluar \\
& & 6. & Stok Barang \\
& & Masuk/Keluar \\
\hline 4 & Menu Keluar & keluar & \\
\hline
\end{tabular}

\section{WONG COCO}

\section{Gambar 2 Form Menu Utama}

\section{c. Form Master Barang}

Form master barang terdiri dari :

\begin{tabular}{|l|l|l|}
\hline 1 & Txt_kb & $\begin{array}{l}\text { Digunakan untuk } \\
\text { memasukan kode } \\
\text { barang }\end{array}$ \\
\hline 2 & Cbb_jenis & $\begin{array}{l}\text { Digunakan untuk } \\
\text { memilih jenis }\end{array}$ \\
\hline
\end{tabular}

\begin{tabular}{|l|l|l|}
\hline & & barang \\
\hline 3 & Txt_nb & $\begin{array}{l}\text { Digunakan untuk } \\
\text { memasukan nama } \\
\text { barang }\end{array}$ \\
\hline 4 & Txt_ukuran & $\begin{array}{l}\text { Digunakan untuk } \\
\text { memasukan } \\
\text { ukuran barang }\end{array}$ \\
\hline 5 & Txt_stok & Digunakan untuk \\
\hline
\end{tabular}




\begin{tabular}{|l|l|l|}
\hline 6 & Btn_tambah & $\begin{array}{l}\text { memasukan stok } \\
\text { Digunakan untuk } \\
\text { memanggil fungsi } \\
\text { tambah data }\end{array}$ \\
\hline 7 & Btn_edit & $\begin{array}{l}\text { Digunakan untuk } \\
\text { memanggil fungsi } \\
\text { edit }\end{array}$ \\
\hline 8 & Btn_simpan & $\begin{array}{l}\text { Digunakan untuk } \\
\text { menyimpan / } \\
\text { update data }\end{array}$ \\
\hline 9 & Btn_hapus & $\begin{array}{l}\text { Digunakan untuk } \\
\text { memanggil fungsi } \\
\text { hapus }\end{array}$ \\
\hline 10 & Btn_keluar & $\begin{array}{l}\text { Digunakan untuk } \\
\text { keluar form } \\
\text { master barang }\end{array}$ \\
\hline 11 & Datagrid & $\begin{array}{l}\text { Digunakan untuk } \\
\text { menampilkan data }\end{array}$ \\
\hline
\end{tabular}

\begin{tabular}{|l|l|l|}
\hline 12 & $<<$ & $\begin{array}{l}\text { barang } \\
\text { Digunakan untuk } \\
\text { menuju ke record } \\
\text { pertama }\end{array}$ \\
\hline 13 & $<$ & $\begin{array}{l}\text { Digunakan untuk } \\
\text { menuju ke record } \\
\text { sebelumnya }\end{array}$ \\
\hline 14 & $>$ & $\begin{array}{l}\text { Digunakan untuk } \\
\text { menuju ke record } \\
\text { berikutnya }\end{array}$ \\
\hline 15 & $>>$ & $\begin{array}{l}\text { Digunakan untuk } \\
\text { menuju ke record } \\
\text { terakhir }\end{array}$ \\
\hline
\end{tabular}

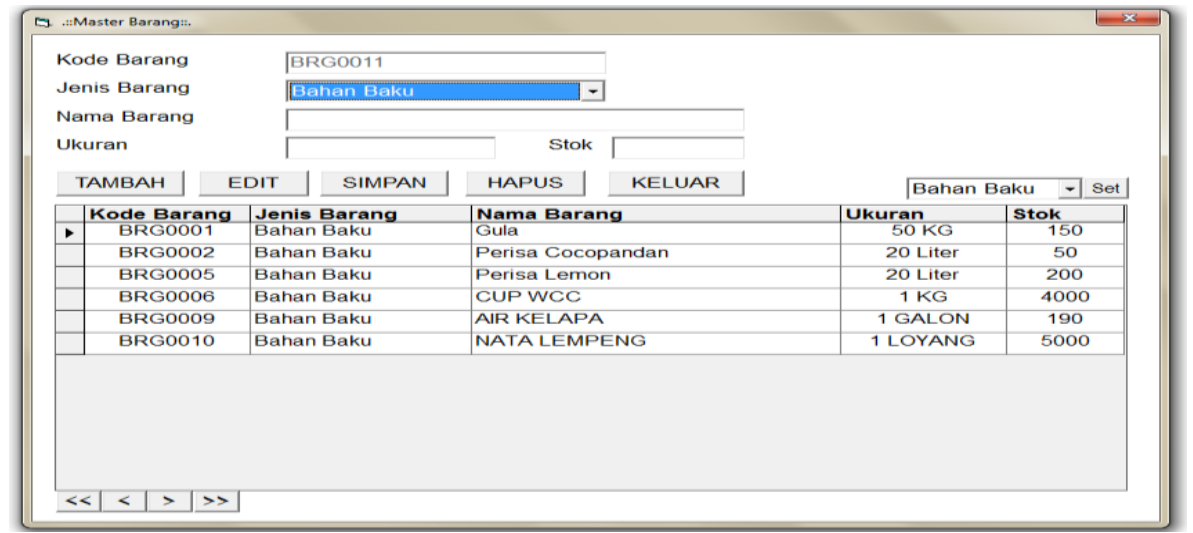

Gambar 3 Form Master Barang

d. Form Master User

Form ini digunakan untuk menambah, ubah, hapus data pengguna aplikasi

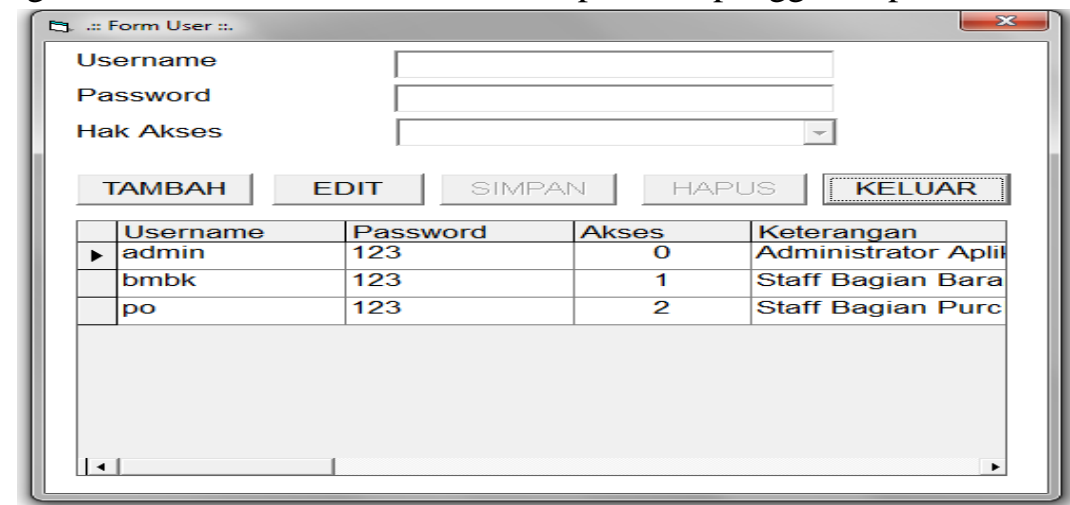

Gambar 4 Form Master User

\section{e. Form Barang Masuk}

Form barang masuk ini digunakan untuk menambah dan mengubah data barang masuk 
1. Tambah

a. Isi txt_asal

b. Isi txt_ket

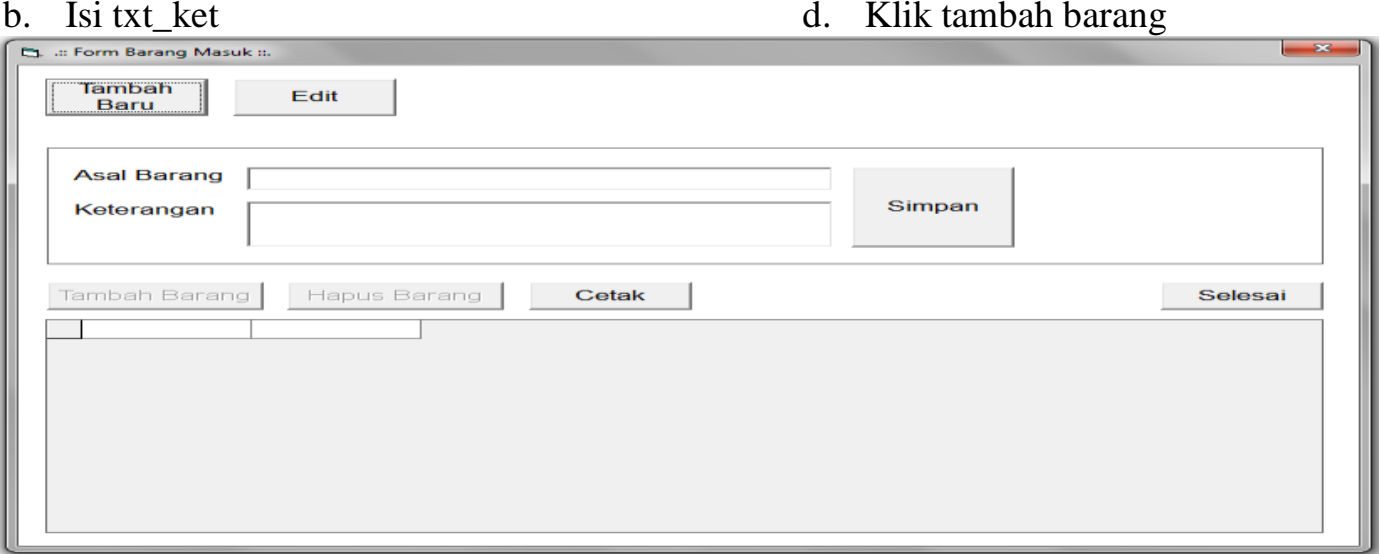

Gambar 5 Form Barang Masuk

Isi txt_cari dengan kode barang kemudian tekan enter, isi jumlah, isi satuan, klik tambah (Barang_masuk1)

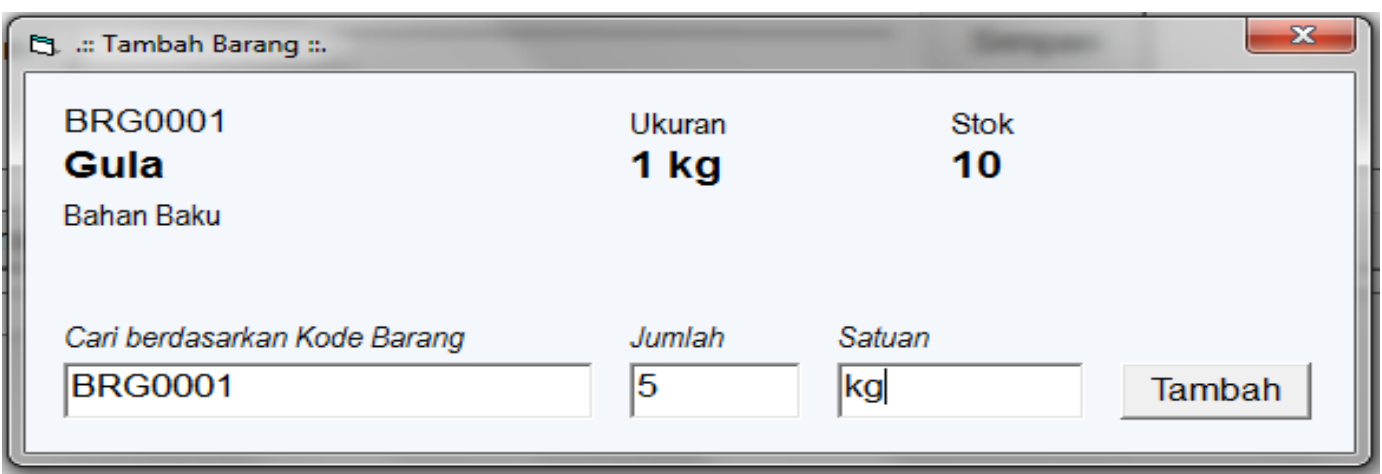

Gambar 6 Form Tambah Barang

a. Klik 2x pada barang yang ingin dihapus

c. Klik cetak (kalau ingin mencetak laporan)

b. Klik hapus barang (kalau barang salah)

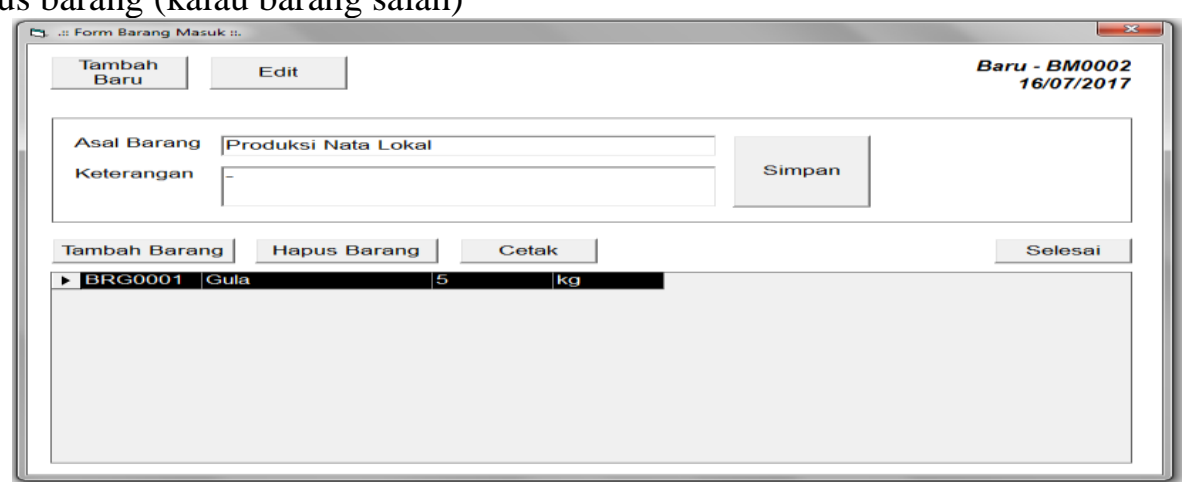

Gambar 7 Form Barang Masuk Cara Hapus

2. Edit

Isikan txt_cari dengan kode barang masuk kemudian enter, maka akan keluar daftar barang masuk di list diatasnya, klik 2x untuk mengeditnya 


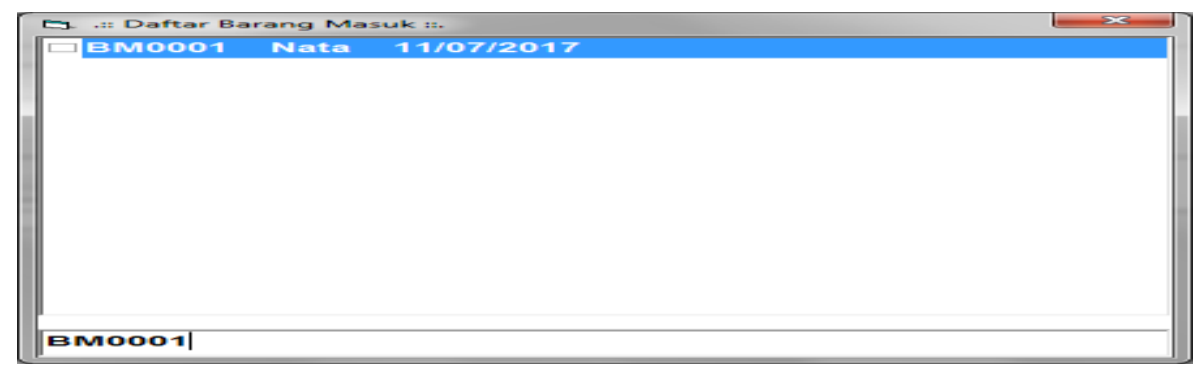

Gambar 8 Form Daftar Barang Masuk

Ubah asal barang dan keterangan jika perlu kemudian tekan simpan, klik tambah barang untuk menambah barang, dan prosesnya sama seperti yang sebelumnya
Catatan : jika ada barang yang berada dibarang masuk, maka barang yang bersangkutan tidak dapat dihapus.

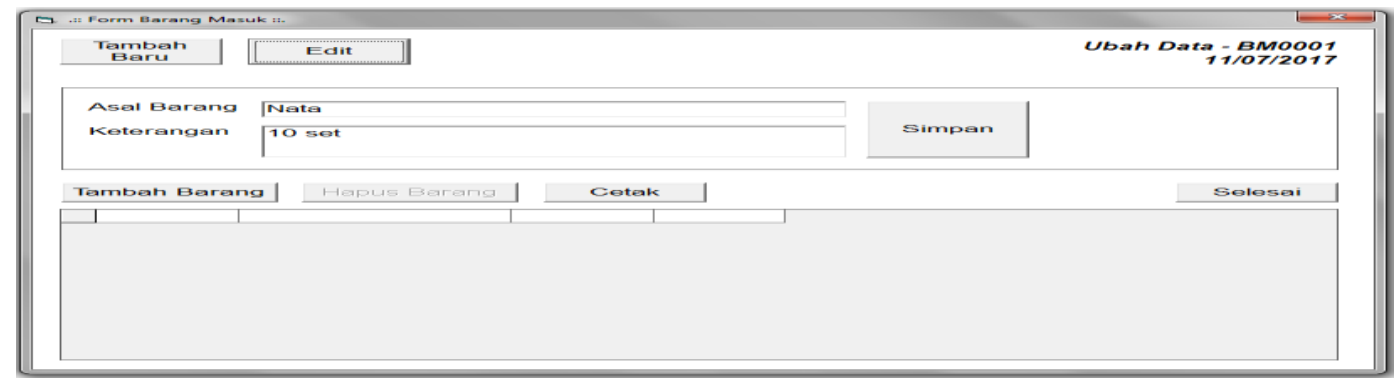

Gambar 9 Form Barang Masuk Ubah Asal Barang

\section{f. Form Barang Keluar}

Form barang keluar ini digunakan untuk mengeluarkan barang sesuai dengan Purchase Order. Berikut beberapa fungsi dari form ini :

a. Isi txt_cari berdasarkan kode po kemudian enter, maka akan keluar tanggal dan daftar barang yang dipesan oleh bagian PO

b. Isi txt_tujuan, txt_ket c. Klik proses (jika daftar barang kosong maka tidak bisa diproses, jika tidak kosong maka disimpan di barang_keluar)

d. Klik cetak jika ingin dicetak

e. Klik selesai untuk keluar dari form barang keluar.

Catatan : jika ada barang yang berada dibarang keluar, maka barang yang bersangkutan tidak dapat dihapus.

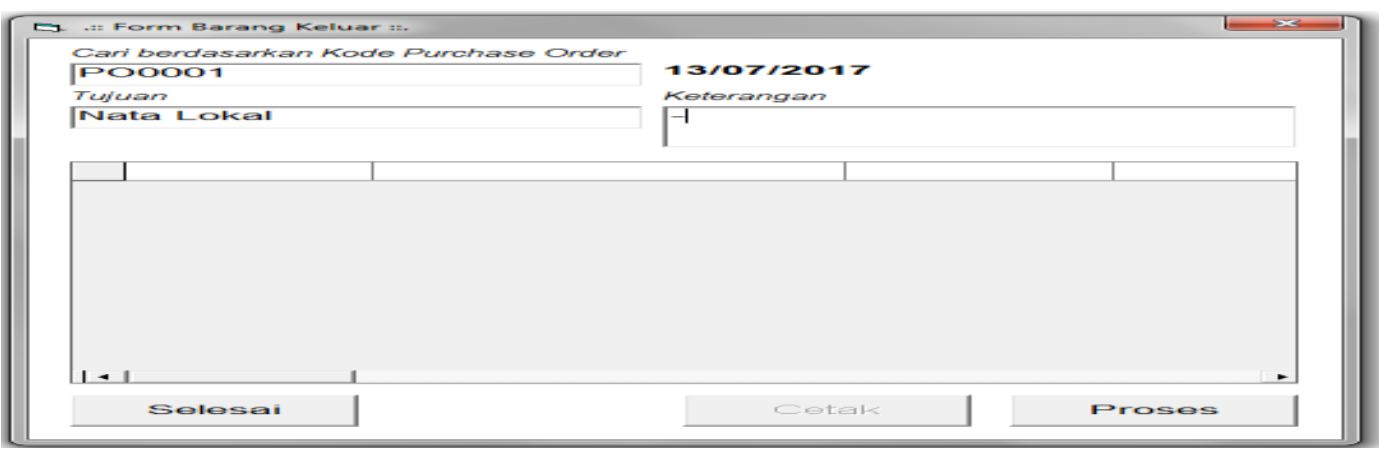

Gambar 10 Form Barang Keluar

\section{g. Form Purchase Order}

Proses form Purchase Order ini sama seperti proses pada form barang masuk. 


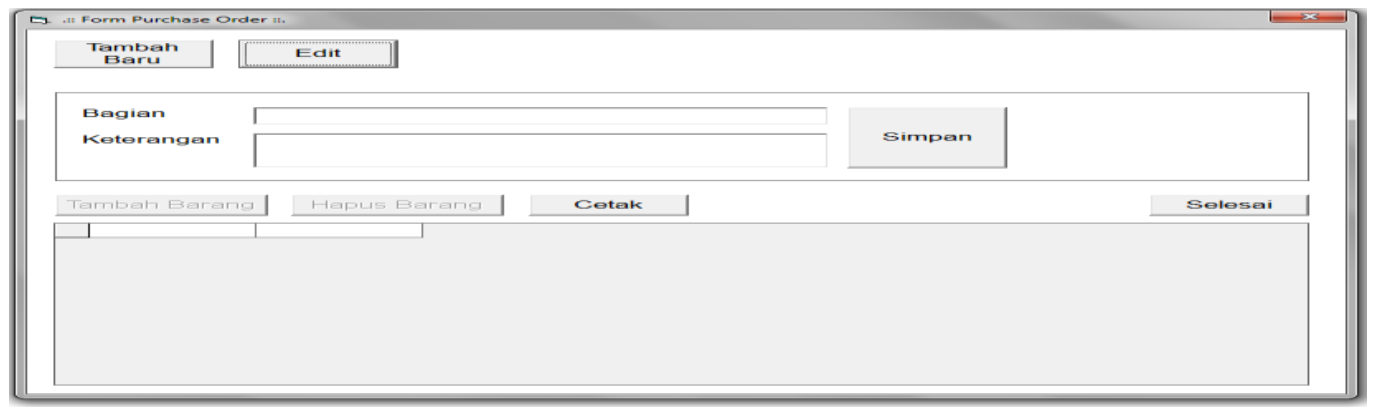

Gambar 11 Form Purchase Order

\section{h. Form Cetak Satuan}

Form cetak satuan digunakan untuk mencetak laporan barang masuk/keluar/po.

Langkah-langkahnya :
Cari berdasarkan kode barang terus enter, kemudian cetak, ini juga berlaku untuk barang keluar maupun PO. digunakan untuk mencetak laporan barang masuk/keluar/po

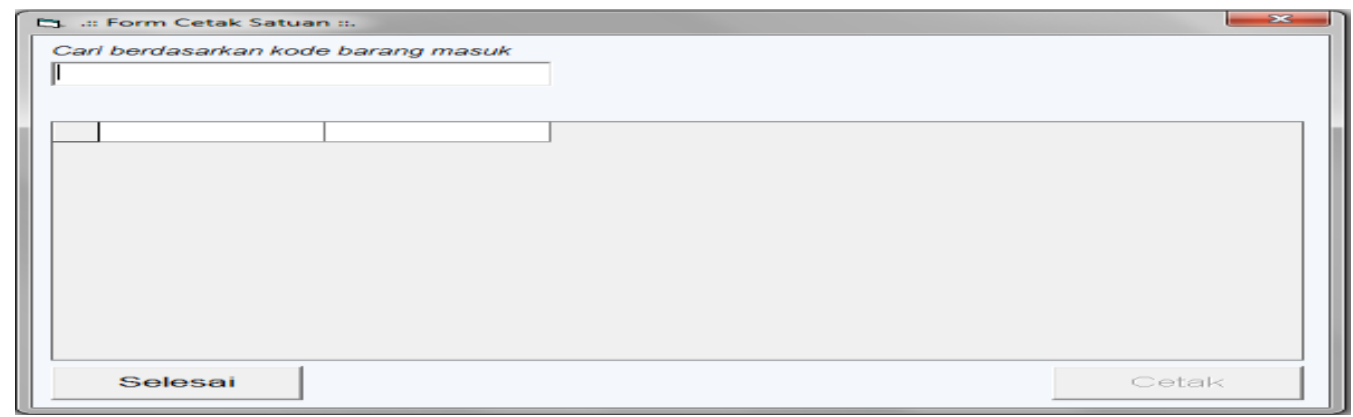

Gambar 12 Form Cetak Satuan

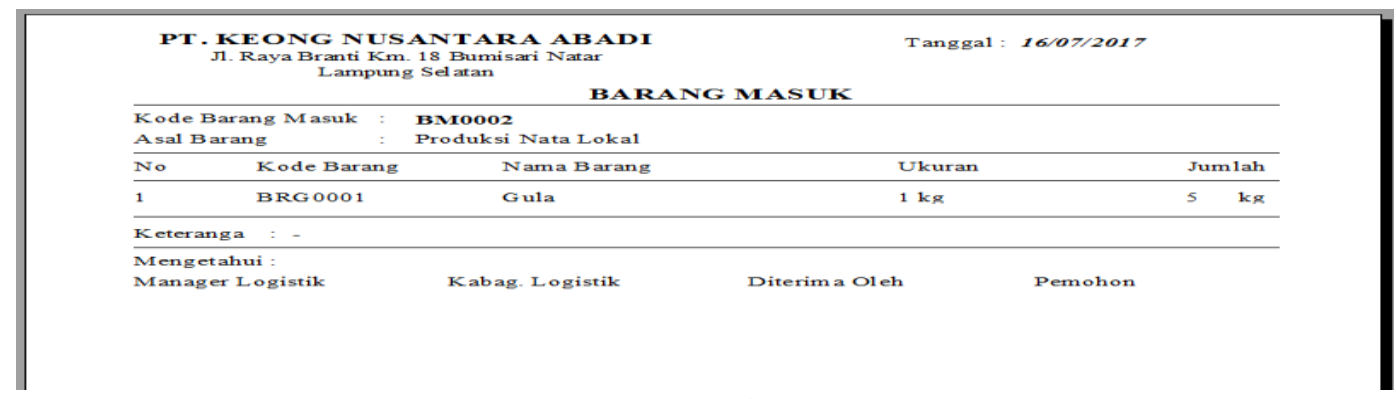

Gambar 13 Hasil Laporan

\section{i. Form Rekap Barang}

Form rekap barang masuk digunakan untuk melihat laporan rekap data barang yang masuk ataupun keluar.

Langkah langkahnya :
Isi tanggal sesuai periode yang ingin dicetak kemudian cetak baik barang masuk/keluar untuk mencetak rekap barang masuk/keluar 


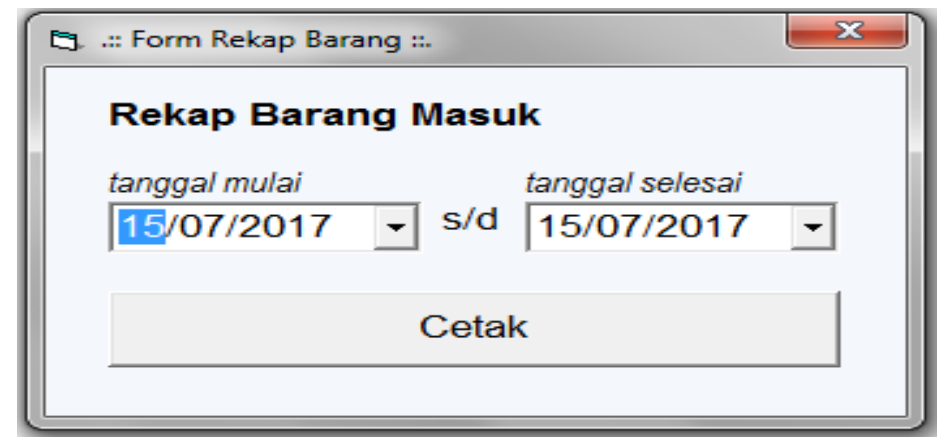

Gambar 14 Form Rekap Barang

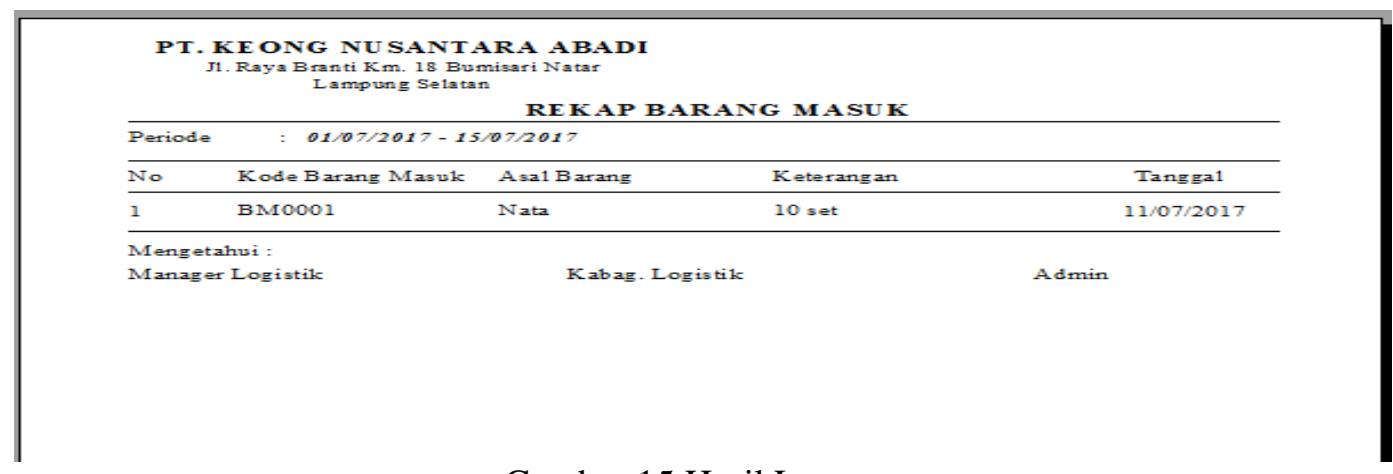

Gambar 15 Hasil Laporan

\section{j. Form Laporan Stok Barang}

Form laporan stok barang digunakan untuk mencetak laporan stok barang masuk/keluar.
Langkah-langkahnya :

Pilih combobox barang masuk/keluar terus pastikan periode tanggal kemudian cetak

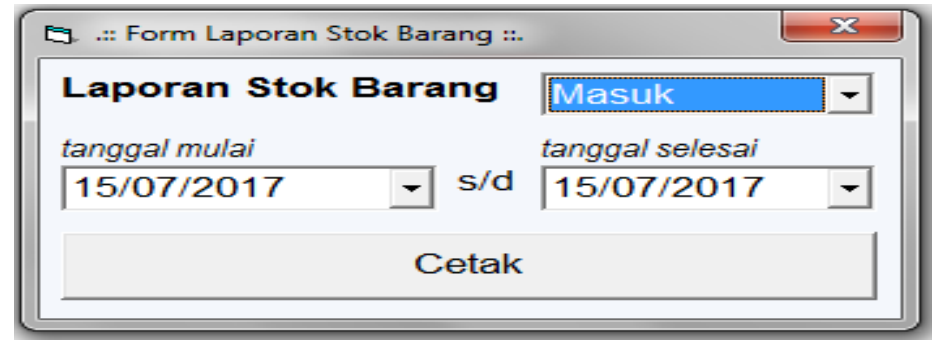

Gambar 16 Form Laporan Stok Barang

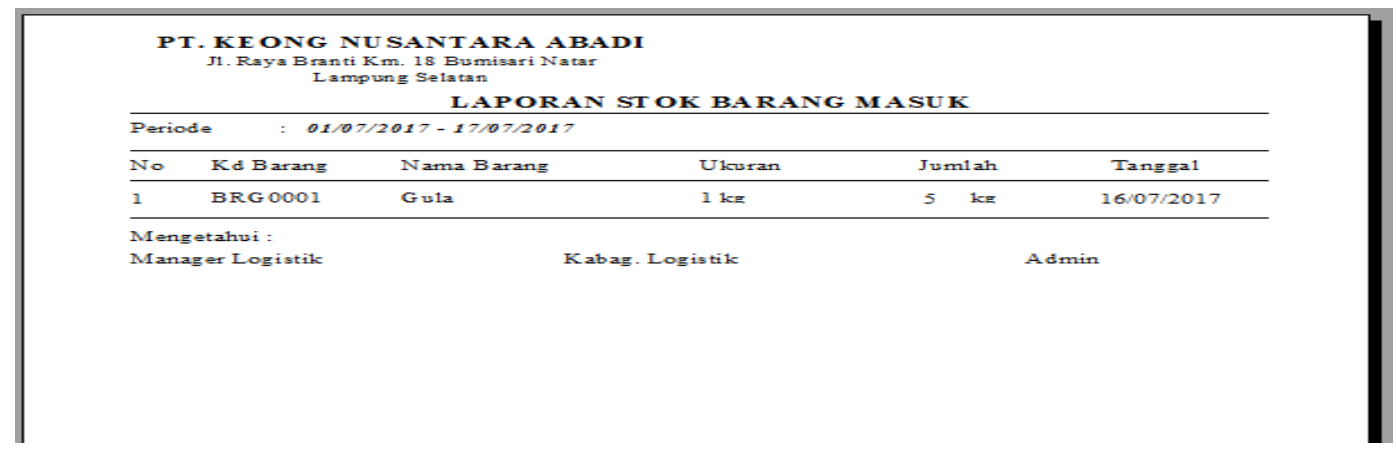

Gambar 17 Hasil Laporan 


\section{KESIMPULAN}

Dari hasil penelitian yang dilakukan penulis, maka penulis dapat mengambil beberapa kesimpulan antara lain sebagai berikut :

1. Aplikasi Sistem Informasi Inventory Control Logistik Berbasis Client Server PT. Keong Nusantara Abadi dapat digunakan sebagai pengganti sistem lama yang masih manual dan dapat menanggulangi permasalahan yang ada pada sistem lama.

2. Hasil pengujian aplikasi pada sistem menunjukkan bahwa sistem mempunyai fungsionalitas yang baik, semua fungsi dan algoritma bekerja sangat baik. Sistem sudah memenuhi spesifikasi kebutuhan.

3. Dalam hal pelaporan, aplikasi ini dapat memudahkan dan mempercepat pembuatan laporan. Oleh sebab itu, Pimpinan perusahaan dapat mengetahui kegiatan operasional keluar masuknya barang serta dapat melihat apa -apa saja yang dibutuhkan untuk keperluan produksi.

\section{SARAN}

Di dalam penelitian ini masih memiliki berbagai keterbatasan, maka perlu dilakukan penyampaian saran untuk kesempurnaan pengembangan sistem bagi peneliti selanjutnya di masa mendatang. Beberapa saran yang dapat penulis sampaikan adalah sebagai berikut :

1. Perlu adanya pemeliharaan aplikasi serta penyempurnaan. Namun demikian diperlukan waktu untuk mengevaluasi sehingga dapat berupa kemungkinan pengembangan fasilitas program yang disesuaikan dengan perkembangan dan kemajuan teknologi.

2. Untuk pengguna (user) yang memahami pemakaian program aplikasi Inventory Control Logistik Berbasis Client Server ini dapat memberikan masukan untuk mengurangi kesalahan dalam penggunaan program sehingga akan melancarkan operasional pada Bagian Logisti dan Produksi PT. Keong Nusantara Abadi.
Agnes Adhiwibowo. 2010, Rancangan Sistem Komputerisasi SIA Persediaan (Studi Kasus Pada Apotik Dadi Sehat Semarang), Semarang.

http://id.wikipedia.org/wiki/Internet, Pengertian dan Sejarah Internet, tanggal akses 09 Juli 2017.

http://sarangeolshop.blogspot.com, 2017, Penjelasan XAMPP, tanggal akses 10 Juli 2017.

http://www.academia.edu, 2013 , Pengertian dan Simbol Flowchart, tanggal 12 Juli 2017.

Jogiyanto,HM. 2005. Analisis \& Desain, Yogyakarta: Andi.

Jogiyanto. 2005, Analisis dan Desain Sistem Informasi, Andi, Yogyakarta.

Ladjamudin, Bin Al-Bahra, 2005, Analisis dan Desain Sistem Informasi, Yogyakarta: Graha Ilmu.

Ni Luh Sari Widhiyani. 2007, Desain Sistem Informasi Akuntansi Persediaan Berbasis Komputer pada Perusahaan Konstruksi, Yogyakarta

Siti Nuraeni. 2011, Perancangan Sistem Akuntansi Persediaan Barang Dagang Terkomputerisasi pada Beta Jaya Furniture dan Bahan Meubel, Yogyakarta.

\section{Daftra Pustaka}


